\title{
Laryngeal Mucositis
}

National Cancer Institute

\section{Source}

National Cancer Institute. Laryngeal Mucositis. NCI Thesaurus. Code C78412.

An inflammatory process affecting the mucous membrane of the larynx. 